\title{
Precocious Germ Cell Differentiation in Amphibia, Produced by the Treatment with Thiourea
}

\author{
K. I. Hanaoka \\ Department of Biology, Faculty of Liberal Arts and Science, \\ Yamagata University, Yamagata
}

Received January 19, 1954

There is a considerable literature concerning the effects of various antithyroid substances upon the morphology and physiology of the thyroid gland and the possible mechanism of the action of these drugs in laboratory animals. But so far as the writer knows, little work has been done on the development of the gonads. The data of Joel, D'Angels and Charipper (1949) indicate that antithyroid substances are effective on the testis of Rana temporaria, but their experiments were carried out on adult frogs only, and no observations were made on the differentiation of the larval gonads. While studying the effects of some chemical substances on sex differentiation in amphibians, the prensent writer found that treatment with thiourea produces precocious germ cell differentiation and an excess of males in the tadpoles of Rana temporaria. The following observation is based on experiments which were performed in 1950 and 1951. Additional work was done in 1951 and 1952 on Hynobius lichenatus for comparison of the effectiveness of the same drug on different forms of amphibia.

The expenses of these investigations were partially defrayed from the Science Research Fund of the Ministry of Education.

\section{Experiments on Rana temporaria}

Rana temporaria in the vicinity of Yamagata City belongs to a semidifferentiated race with regard to sex differentiation, and in the male, each gonad has distinct ovarian cavity lined with rete cells. The testes, however, are distinguished from the ovaries of the famale by the differentiation of the germ cells. With the onset of metamorphosis, the germ cells of the female grow into large ova provided with vesicular nuclei; but in the testes, the gonia in the cortex never assume the structure of female germ cells. Remnants of ovarian cavities are found in some males after complete metamorphosis.

Administration of thiourea was carried out simply by maintaining the tadpoles in a solution of the drug in tap water. The experimental animals were kept in a large glass bowl containing two liters of the solution and fed on boiled vegetables. At various intervals they were fixed in Bouin's 
solution and the gonads, thyroid glands and hypophysis were sectioned at $8 \mu$ by the ordinary paraffin method and stained with haematoxylin and eosin.

A. Experiments on young tadpoles. In Spring of 1950 preliminary experiments were made on young tadpoles. In Table 1, the distribution of

Table 1. Sex differentiation of Rana temporaria treated with $0.1 \%$ and $0.2 \%$ solutions of thiourea

\begin{tabular}{|c|c|c|c|c|c|c|c|c|c|}
\hline \multirow{3}{*}{ A } & \multirow{2}{*}{\multicolumn{2}{|c|}{ Treatment }} & \multirow{2}{*}{$\begin{array}{l}\text { Date of } \\
\text { fixing }\end{array}$} & \multicolumn{4}{|c|}{ Sexes } & & \multirow{2}{*}{ Notes } \\
\hline & & & & Undiff. & $\hat{\alpha}$ & 우 & 우 & & \\
\hline & \multirow{2}{*}{\multicolumn{2}{|c|}{$\begin{array}{c}0.1 \% \text { solution for } \\
40 \text { days (March } 28- \\
\text { May 11) }\end{array}$}} & May 29 & $\begin{array}{l}2 \\
2\end{array}$ & 1 & & 1 & \multicolumn{2}{|c|}{$\begin{array}{l}\text { Total length } \\
30-32 \mathrm{~mm}\end{array}$} \\
\hline A & & & $\begin{array}{cr}\text { Jul. } & 13 \\
: & 31 \\
\text { Aug. } & 6 \\
: & 26\end{array}$ & & 3 & $\begin{array}{l}2 \\
2\end{array}$ & $\begin{array}{l}2 \\
1\end{array}$ & & Complete \\
\hline B & $0.1 \%$ & \multirow{2}{*}{$\begin{array}{c}\text { Solution for } \\
16 \text { days } \\
\text { (April 25- } \\
\text { May 11) }\end{array}$} & $\begin{array}{c}\text { Jun. } 15 \\
: \\
\text { Jun. } 26\end{array}$ & & $\begin{array}{l}3 \\
4 \\
4\end{array}$ & 1 & $\begin{array}{l}2 \\
2 \\
3\end{array}$ & 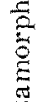 & $\begin{array}{l}\text { Incomplete } \\
\text { Complete } \\
\text { Incomplete }\end{array}$ \\
\hline \multirow[t]{2}{*}{ C } & \multirow{2}{*}{$0.2 \%$} & & $\begin{array}{cc}\text { Jun. } & 15 \\
: & \\
\text { Jun. } & 24 \\
: & \end{array}$ & & $\begin{array}{l}4 \\
4 \\
4\end{array}$ & $\begin{array}{l}1 \\
1 \\
1\end{array}$ & $\begin{array}{l}4 \\
4 \\
4 \\
4\end{array}$ & $\sum_{\Sigma}^{\infty}$ & $\begin{array}{l}\text { Complete } \\
\text { Incomplete } \\
\text { Complete } \\
\text { Incomplete }\end{array}$ \\
\hline & & & & 4 & 27 & 8 & 27 & & (66) \\
\hline
\end{tabular}

At the beginning of the experiment, the tadpoles of group A were $10 \mathrm{~mm}$ in total length and were provided with external gills. In groups B and C they were $30 \mathrm{~mm}$ or more in total length.

the sexes in animals preserved at different times of development is represented. It must be noticed that the development of these tadpoles was more or less retarded; the tails were crooked near the junction of the abdomen and their metamorphosis was delayed three or more weeks after that of the control animals. Moreover, two-thirds or more of the treated animals died before the beginning of metamorphosis. An indication of the effect of the thiourea, however, was seen in an acceleration of germ cell differentiation in both males and females. With the onset of metamorphosis, the ovarian cavities in the testes were completely obliterated with rete cells and the gonia were found forming early seminal tubules. In the females, each ovum increased in size and the whole ovary became several times as large as that of control females.

Some conspicuous influences of thiourea upon sex differentiation were observed in hermaphroditic animals. The gonads of these animals were always solid, with well differentiated medullary tissue, but various numbers of germ cells were growing into distinct ova which in structure as well as in size were indistinguishable from ova of treated females. 
B. Experiments on large tadpoles. The use of $0.1 \%$ and $0.2 \%$ solutions of thiourea in the foregoing experiments affected the growth of the tadpoles adversely, and resulted in a high rate of mortality. In the experiments of 1951, therefore, the concentration of thiourea was decreased to $0.025 \%$, and tadpoles of large size were raised in the solution. At the beginning of the experiment these tadpoles showed the larval form in every respect except that tiny buds of the hind limbs were just appearing. Unexpectedly, the metamorphosis of these treated animais proceeded to various degrees, and in some of them relatively large and powerful hind-limbs or even rudimentary fore-limbs developed under the operculum and the broad, rounded outline of the head changed to a narrow, more pointed adult type in the few weeks of the experiment. But further metamorphic changes were completely inhibited; the animals retained the larval mouth accessaries and long tail as long as treatment continued, and increased in size until they attained, at the end of the experiment, an average length of $55 \mathrm{~mm}$, the length of the control animals being $39.6 \mathrm{~mm}$.

In all these tadpoles, differentiation of the gonads was found to have been remarkedly accelerated; in the testes, the formation of seminal tubules was completed at the end of June and in the middle of August sperm formation was going on (Fig. 3). The females always had large ovaries containing well developed eggs which showed far advanced stages of germ cell differentiation (Fig. 5). The distribution of sexes in these animals was most interesting. Of 58 experimentals, 40 were males, 16 females and 2 were hermaphrodites. The 2 last mentioned specimens were predominantly males, provided with well differentiated testes of the solid type. These contained,

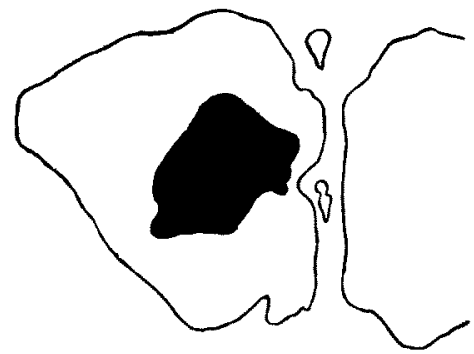

Fig. A. Comparison of sections through the widest part of the thyroid glands; white, tadpole treated for 5 months with $0.025 \%$ solution of thiourea; black, control just before metamorphosis. however, both matured spermatozoa and ova of a considerable size.

C. Changes in thyroid glands and hypophysis. Treatment with a $0.025 \%$ solution of thiourea produced in all the experimental animals marked hypertrophy and well defined histological changes in the thyroid glands (Fig. A). The first indication of these changes was seen in the definite increase of vascularity which was indicated by the enlarged vessels and an increased number of blood cells. The follicular epithelium of the gland changed from a low columnar to a high columnar type and the amount of intra-follicular colloids increased greatly. Around the periphery of the colloid mass there appeared many chromophobe droplets but none of them was detected within the epithelial cells. These interacting changes caused the whole gland to hypertrophy to a conspicuous degree (Fig. 1). 
The effects of thiourea observed in the thyroid gland of the treated animals were in close agreement with those reported in other forms of amphibians. It must be noticed, however, that hypertrophy of the thyroid
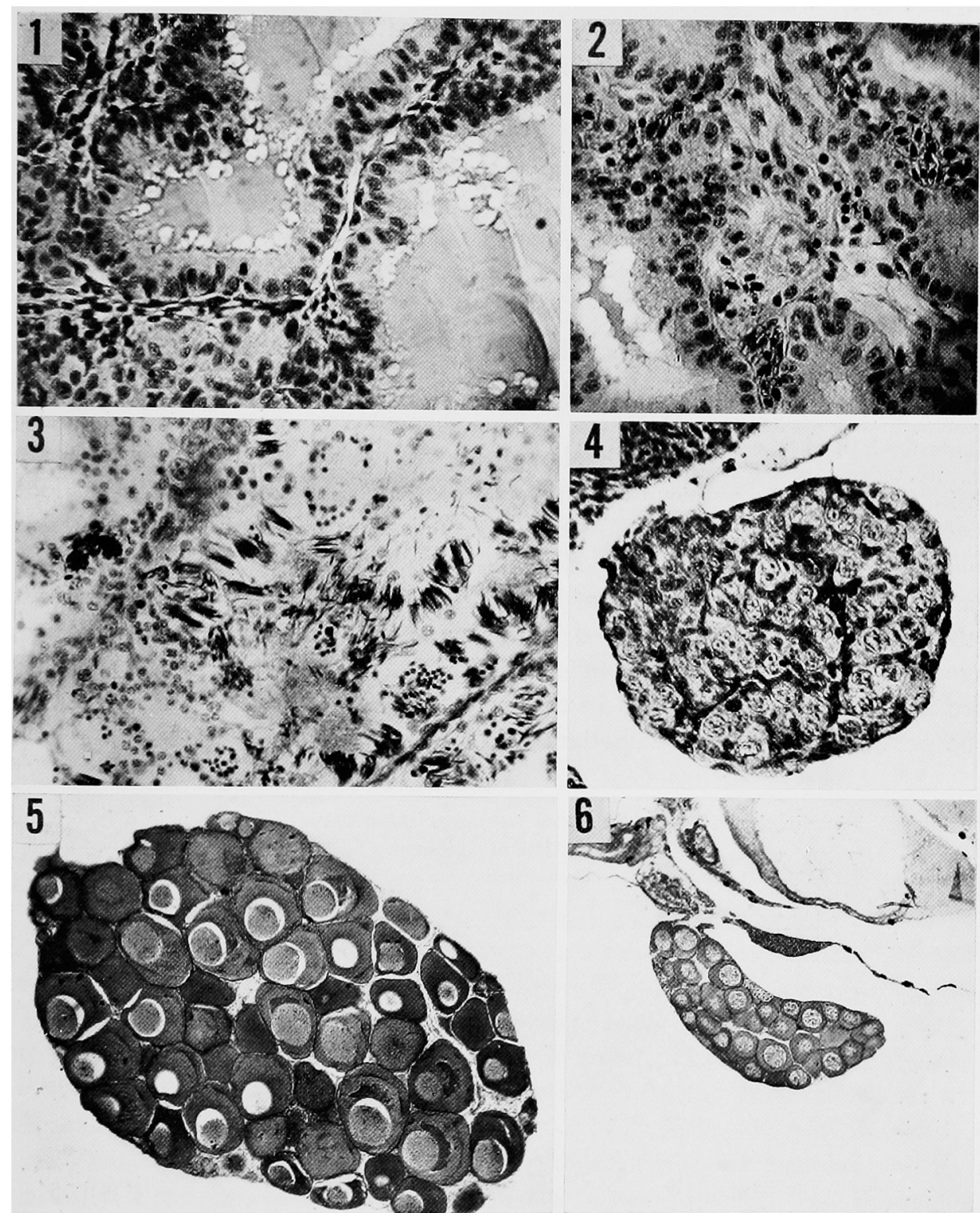

Figs. 1-6. 1. Thyroid gland from a tadpole treated for 5 months with $0.025 \%$ solution of thiourea. 2. Normal thyroid gland in a tadpole just before metamorphosis. 3 Spermatogenesis in the testis of a tadpole treated for 5 months with $0.025 \%$ solution of thiourea. 4. Normal testis from a tadpole just before metamorphosis. 5. Ovary from a tadpole treated for 5 months with $0.025 \%$ solution of thiourea. 6. Normal ovary from a tadpole just before metamorphosis. 
gland in the treated animals remained evident for more than 170 days of treatment.

The hypophyses of animals whose thyroid gland exhibited maximum hypertrophy were studied along with those of the control animals. As already described, the germ cells in these treated animals showed far advanced stages of sex differentiation.

In the hypophysis of Rana temporaria larvae two kinds of secretory cells are distinguishable; the one, rather large in size, has clear cytoplasm which stains red with eosin, and the other has granular cytoplasm which shows less affinity to dyes. In both of these cell the nucleus is relatively large and centrally located. The cells of the third type have small nuclei

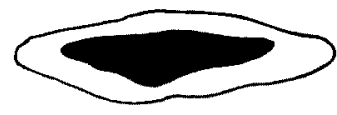

Fig. B. Comparison of sections through the widest part of the anterior lobe of the hypophysis; white, tadpole treated for 5 months with $0.025 \%$ solution of thiourea; black, control just before metamorphosis. which stain heavily with haematoxylin. Presumably they do not belong to the secretory element, and are difficult to identify in many specimens.

The hypophyses of affected tadpoles showed extraordinarily large development and this was particularly so in the anterior lobe (Fig. B). Histological observations revealed that the treatment produced, in some animals, an increase in the proportion of basophilic cells. It appeared, however, that the staining lechnique employed in the present investigation did not produce good results for precise histological observation of the hypophysis. Detailed consideration of the changes in the cells of the hypophysis will, therefore, be postponed to another investigation.

Table 2. Distribution of sexes in Rana temporaria larvae which were raised in $0.025 \%$ solution of thiourea

\begin{tabular}{|c|c|c|c|c|c|c|c|}
\hline \multirow{2}{*}{\multicolumn{2}{|c|}{$\begin{array}{l}\text { Date of } \\
\text { fixing }\end{array}$}} & \multicolumn{3}{|c|}{ Sexes } & \multicolumn{3}{|c|}{ Total length } \\
\hline & & 今 & 우 $\rightarrow$ & 우 & Largest & Smallest & Mean \\
\hline $\begin{array}{l}\text { Jun. } \\
\text { : }\end{array}$ & $\begin{array}{l}21- \\
27\end{array}$ & 1 & & 2 & 44 & 34 & 40.0 \\
\hline Aug. & 11 & 1 & & 3 & 53 & 44 & 49.6 \\
\hline : & 25 & 1 & & & & & \\
\hline Sept. & 25 & 12 & 1 & 2 & & & \\
\hline Oet. & 8 & 4 & & & 60 & 51 & 56.0 \\
\hline & 22 & 12 & & 5 & 60 & 49 & 52.9 \\
\hline Dec. & 12 & 9 & 1 & 4 & 60 & 53 & 55.8 \\
\hline Tot: & & 40 & 2 & 16 & & & \\
\hline
\end{tabular}

The experiment was begun on the $23 \mathrm{rd}$ of May. The mean length of 10 specimens collected in the field (July 9) was $48 \mathrm{~mm}$ and the mean length of 10 specimens raised in the laboratory (July 23 ) was $39.6 \mathrm{~mm}$. 


\section{Experiments on Hynobius lichenatus}

An additional experiment was made on a relatively small number of salamander larvae, Hynobius lichenatus, for comparison with Rana temporaria. These larvae were all raised in a $0.025 \%$ solution of thiourea, and chiefly its influence on sex differentiation was observed. At the beginning of the experiment the larvae were $40 \mathrm{~mm}$ in average length but after 14 months, when the experiment was terminated, some of the animals had become as large as $83 \mathrm{~mm}$ in total length, the intermediate size of adult salamanders of this form being $90-100 \mathrm{~mm}$.

In general the results obtained in the present series of experiment correspond well with those observed in the previous investigations. Metamorphosis of the treated animals was completely inhibited and all of the giant larvae had well-developed external gills and a broad fin on the tail.

Table 3. Distribution of sexes in Hynobius lichenatus treated with $0.025 \%$ solution of thiourea

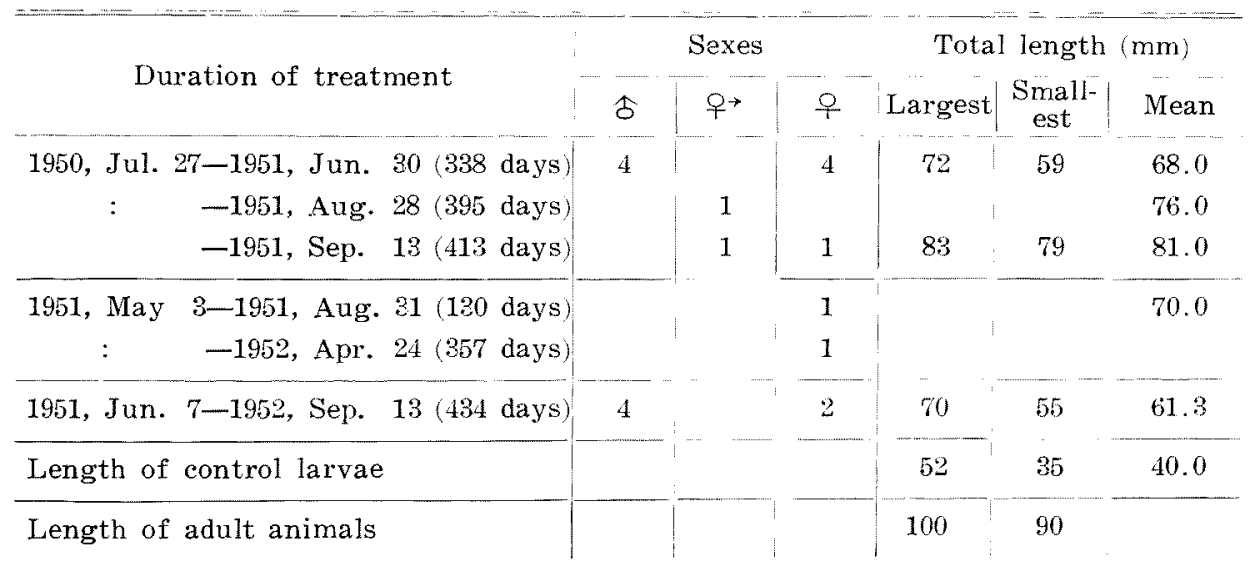

Normal sex differentiation in $H$. lichenatus in relation to age was described by Aoto (1947). According to him, spermatogenesis begins in the comparatively well developed testes of 2 -year-old males. In animals treated with thiourea, the first indication of spermatogenesis was observed as early as August of the second year; and in the following September and October, bundles of fully matured spermatozoa were found in the seminal tubules of all males.

In the ovaries of 1-year-old females, some of the oocytes became remarkedly large and were provided with large vesicular nuclei. The cytoplasm around the nuclei consisted of a thick layer of fine granular substances which stained red with eosin. In the peripheral zone of the cytoplasm, on the other hand, yolk granules were accumulated which stained heavily with haematoxylin and between the two layers there were networks of coarser and less stainable substances. Aoto gave no description of the oocyte 
sturcture in the ovaries of 2 - or 3-year-old females, but the eggs in the treated females described above show clearly a stage of differentiation further advanced than those of corresponding normal females.

\section{Discussion}

Administration of a relatively low concentration of thiourea to Rana temporaria prevented metamorphosis of tadpoles and produced marked hypertrophy in the thyroid gland as well as in the hypophysis. Histological studies have revealed that changes observed in the affected secretory glands correspond in general to those already described in other forms of amphibians. In some frogs (Gordon, Goldsmith and Charipper, 1943, Joel, D'Angelo and Charipper, 1949) and in newts (Wheeler, 1953) it was reported that after long continued treatment with relatively high concentrations of antithyroid substances, a decrease in thyroid size was observed and this regression was presumed to result from the exhaustion of the thyrotrophic activity of the hypophysis.

In the present experiment, however, it was found that the changes produced by the treatment with $0.025 \%$ solution of thiourea remained stable for more than 6 months, or even an increase in the size of thyroid glands was observed in some animals preserved until a later period of the experiment. The larval hypophysis of $R$. temporaria seems, therefore, to have a higher potency to react to the stimulus produced by the treatment with thiourea.

An interesting effect of thiourea was indicated in the modification of sex differentiation in the treated tadpoles. Among 66 animals which were treated with a relatively high concentration of the drug, 8 differentiated into hermaphrodites with gonads containing both spermatogonia and large ova. Histologically these hermaphroditic gonads assume the structure of testes in which some gonia have developed into young eggs. Concerning the formation of ova in the tesis it must be remembered that the frog used in the present experiments belongs to a hermaphroditic race and the male gonads are provided with a rather well differentiated cortical germ layer. In a previous experiment on Hynobius retardatus, the present writer (Hanaoka, 1939) reported that cortical germ cells in the male gonads are stimulated to grow into ova by the implantation of adult hypophysis. In the present experiment, cortical germ cells in the male tadpoles must have been stimulated by a compensatory over production of hypophysial hormone which was caused by the decreased content of thyroid hormone in the blood.

Administration of $0.025 \%$ solution of thiourea to tadpoles of relatively large size produced, among 58 animals, 2 hermaphroditic males and also a marked excess of males (males: 40, hermaphrodites: 2, females: 16). Statistical treatment shows that reversal of sex from female to male has occurred in this group of experimental animals $[F(38.80)<F(30.60)=2.0285<2.1053]$. 
The decrease in the number of hermaphroditic males in this group is evidently due to the fact that in tadpoles near metamorphosis the number of cortical germ cells is rapidly decreased. But the present writer cannot offer any adequate explanation for the mechanism of sex reversal induced by the treat. ment with antithyroid substance. General metabolic changes produced by hormonal disorder might have affected the medullary tissue of female gonads, in some way, resulting in the development of testes.

As for the secretory elements in the anterior lobe of the hypophysis two types of cells, basophils and acidophils, are distinguishable and much work of previous investigators indicates that after thyroidectomy definite changes occur in basophils. According to Gasche and Druey (1946), the hypophyses of Xenopus laevis larvae raised in a thiourea solution exhibited a rapid increase in basophilic cells. Wheeler (1953) also observed, in adult animals of Desmognathus fuscus brimleyorum, that treatment with antithyroid substances produced a similar increase in the proportion of basophilic cells and a decrease in the relative number of acidophilic cells. All these observations tend to support the conception of Griesbach (1941) that basophils are the source of the thyrotrophic hormone.

In the present experiment it was not possible to ascertain by histological observation whether any change in the acidophilic cells regularly occurs in the hypophysis of the Rana temporaria tadpole. It is evident, however, that not only the thyrotrophic element but also the gonadtrophic element of the hypophysis is activated by treatment with thiourea. The gonadtrophic activity of the hypophysis was most clearly indicated in the acceleration of germ cell differentiation in the gonads of giant tadpoles of Rana temporaria and Hynobius lichenatus; their testes contained bundles of fully matured spermatozoa, and large eggs with yolk granules in the cytoplasm were found in the ovaries. Horie (1941) obtained, in tadpoles of Rana temporaria raised in a $\mathrm{KMnO}_{4}$ solution, a certain number of giant specimens which, in external appearance as well as in the histological structure of the gonads and hypophysis, are similar to the specimens produced in the present experiments. However, he gave no description of changes in the thyroid glands. The results of his experiment, however, are open to question because his own repetition of the same experiment produced neither giant tadpoles nor precocious germ cell differentiation in the gonads.

\section{Summary}

1. Administration of a $0.025 \%$ solution of thiourea to tadpole of Rana temporaria prevented metamorphosis and produced a definite hypertrophy in the thyroid gland as well as in the hypophysis. Histological changes observed in the affected glands correspond in general "to those reported by 
previous authors, but they persisted intact for more than 6 months of treatment.

2. Treatment with $0.1 \%$ or $0.2 \%$ solution of the same drug produced in tadpoles of Rana temporaria a relatively high percentage of hermaphroditic males whose testes contained various numbers of young ova.

3. Treatment with a $0.025 \%$ solution produced a marked excess of males. Statistical treatments show that sex reversal from female to male has occurred in this group of experimental animals.

4. Germ cell differentiation in the gonads of treated animals proceeded far ahead of that in the control animals; in the testes of Rana temporaria, bundles of spermatozoa were observed as early as September of the first year. Larvae of Hynobius lichenatus also exhibited an accelerated differentiation of germ cells in both males and females.

\section{Literature cited}

Aoto, T. 1947. Sexual phases in a Japanese salamander, Hynobius lichenatus Boul., in relation to the age of animals. Jour. Fac. Sci. Hokkaido Univ., Ser. 6, Zool. 9 , 4 .

Gasche, P. and Druey, 1946. Wirksamkeit schilddrüsenhemmender Stoffe auf die Xeno pus metamorphose. Experientia 2.

Gordon, A. S., Goldsmith E. D. and Charipper, H. A. 1943. Effect of thiourea on the development of the amphibian. Nature 152.

Griesbach, W, E. 1941. Changes in the anterior pituitary of the rat, produced by Brassica seed diet. Brit. J. Exp. Path. 22.

Hanaoka, K. I. 1989. Modification of sex in a salamander Hynobius retardatus induced by the transplantation of testis and hypophysis. Jap. Jour. Zool. 8, 3 .

Horie, H. 1941. Effect of potassium-permanganate on the tadpoles of Rana temporaria Proc. Imp. Acad. Tokyo 17.

Joel, T., S. A. D'Angelo and H. A. Charipper 1949. The effect of thiourea on the thyroid gland of winter frogs (Rana pipiens) with some observation on the testis. J. Exp. Zool. 110.

Wheeler, A. J. 1953. Temporal variation in histological appearance of thyroid and pituitary of salamanders treated with thyroid inhibitors. Biol. Bull. 104, 2. 